\title{
Successful online learning factors in COVID-19 era: Study of Islamic higher education in West Papua, Indonesia
}

\author{
Agus Yudiawan', Budi Sunarso², Suharmoko ${ }^{3}$, Fatma Sari ${ }^{4}$, Ahmadi $^{5}$ \\ $1,3,4,5$ Majoring in Tarbiyah, IAIN Sorong, West Papua, Indonesia \\ ${ }^{2}$ Faculty of Tarbiyah and Teacher Science, IAIN Salatiga, Central Java, Indonesia
}

\begin{abstract}
Article Info
Article history:

Received Sep 16, 2020

Revised Jan 26, 2021

Accepted Feb 7, 2021

Keywords:

COVID-19 era

Infrastructure

Islamic education

Online learning

System quality

ABSTRACT

This study aimed to map and tests the factors that influence online learning success in the COVID-19 era in Islamic Religious Higher Education in the West Papua region. Factors to be analyzed are student characteristics, internal motivation, instructor characteristics, quality of institutions and services, infrastructure and system quality, quality of courses and information, online learning environment. The sample size obtained from the Slovin formula was 302 students. Data collected through surveys by distributing questionnaires. Analysis of the regression model used to carry out data analysis. The results showed that the seven factors tested influenced online learning success in the COVID-19 era, with varying significance. Infrastructure and system quality are the most dominant influences (94.2\%), while institutions' variety and services have no significant impact $(6.3 \%)$. The conclusion is that the seven factors can be used to determine the success of online learning in the COVID-19 era in Islamic Religious Higher Education in the West Papua region.
\end{abstract}

This is an open access article under the CC BY-SA license.

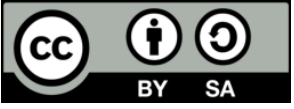

\section{Corresponding Author:}

Agus Yudiawan

Majoring in Tarbiyah

IAIN Sorong

Jalan Sorong Klamono Km. 17 Klablim, Sorong City, West Papua, Indonesia

Email: agusyudiawan@stainsorong.ac

\section{INTRODUCTION}

The COVID-19 pandemic has massively changed the learning model. Learning that is generally done face-to-face is now transformed into a network or online. The relevant ministry stated that all universities in all zones were prohibited from face-to-face lectures and switched online [1, 2]. Online learning is a less famous but appropriate choice in deciding the physical interaction between students and lecturers; the aim of COVID-19 can be controlled [3]. Similarly, the Islamic Religious College in the West Papua region is a compliant step towards academic authority and safety policy.

However, online learning that has been carried out since mid-March 2020 until now needs to be evaluated comprehensively. Higher education in developed regions is undoubtedly not a problem, but in developing areas such as West Papua, the conditions are different $[4,5]$. Infrastructure preparation in the form of an application platform and readiness of human resources must be done immediately. Infrastructure and facilities will not be useful if the users (teachers and students) are not ready to run it [6].

So far, studies on the implementation of online learning during the COVID-19 period have two general trends. First, courses that are online learning at a normative level, both concerning user perceptions [7], implementation [8-12], as well as the technology platform, used [13, 14]. The second trend is related to evaluation [15], including how the impact of online learning, barriers, and relevant educational policy models 
in supporting online learning [16-19]. Several studies have found that the most common obstacles to online learning are access issues (network and ownership of smart phone and computers) and funding issues (data pulses).

Of the two trends, which examines the success factor of online learning during the COVID-19 period, especially in Islamic tertiary institutions, it looks very minimal. Especially in West Papua, this has not even been done. Whereas in West Papua, there are three Islamic Religious Higher Education, with 68 educators and 1299 students [20], which are institutional assets that should receive attention. Islamic Religious Higher Education in West Papua was chosen based on academic concern, with minimal studies related to COVID-19 in Islamic Religious Higher Education. In addition, three Islamic religious tertiary institutions in developing regions have become quite relevant in testing theories in previous studies.

This study seeks to complement the studies that have been conducted. This study will examine the factor of online learning success in Islamic Religious Higher Education during the COVID-19 period. Three dimensions with seven parameters are used to measure the Critical Success Factor (CFS) of online learning in developing regions. First, the personal dimension with parameters of student characteristics [8, 9], internal motivation [21-24], and instructor/lecturer characteristics [25-27]. Second, the system's dimensions with parameters of the quality of institutions and services, infrastructure, and quality of the system, the quality of courses and information $[10,12]$. Third, the dimensions of the environment with online learning environment parameters [25]. These seven parameters will be tested in relation to the successful implementation of online learning in the area of West Papua. The parameters referred are shown in Figure 1.

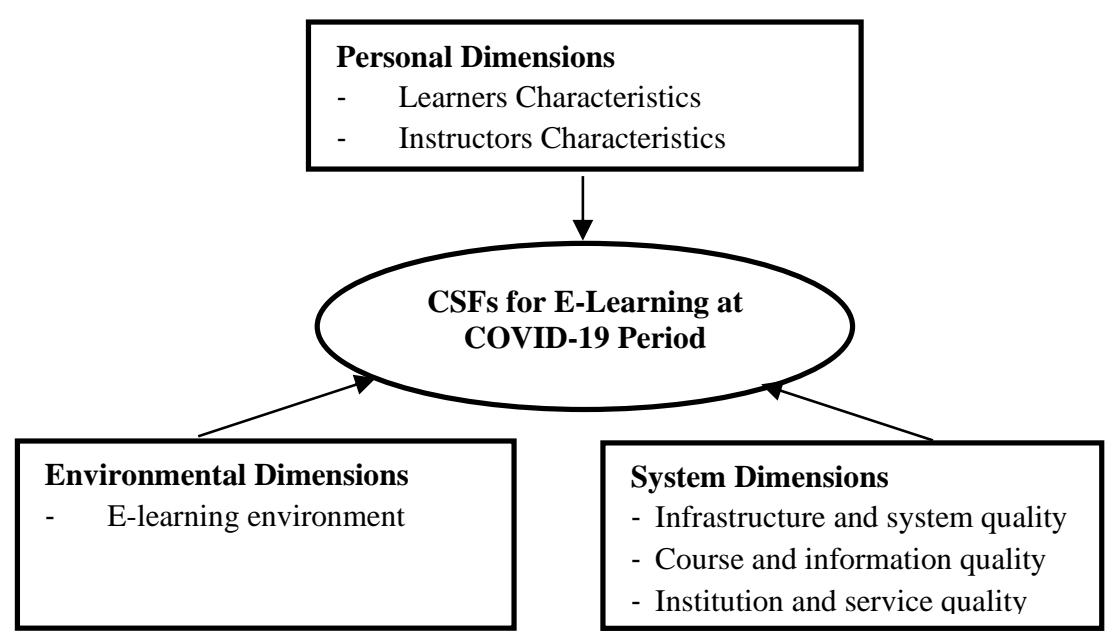

Figure 1. Research framework [25]

Figure 1 explained the research hypothesis that there is a positive and significant influence on learners' charismatics, instructors' charismatics, extrinsic motivation, e-learning environment, infrastructure, and system quality, course and information quality, and institution and service quality partially on the successful implementation of online learning in COVID-19 period in Islamic Religious Higher Education in West Papua region.

\section{RESEARCH METHOD}

The study was designed using quantitative research methods. The population of 1367 spread over three Islamic religious colleges in West Papua. The number of samples was determined according to the Slovin formula with a margin of error of 5\% and obtained 302 samples. Samples were taken by a multistage random sampling technique where each Islamic Religious Higher Education sample is represented proportionally. Furthermore, the data was collected through a survey by distributing a Likert scale questionnaire (1-5) to all samples with the help of Google Form. The questionnaire is always distributed, and the validity and reliability are first ascertained using the help of IBM SPPS software. 21.0. So that the questionnaire can measure according to what is expected in the study. The instrument is valid if the value of sig. (2-tailed) $<0.05$, and reliable if Cronbach's Alpha value $>0.6$ [28]. The questionnaire validity and reliability test results showed 64 items of instrument questions had a sig value. (2-tailed) is far below 0.05 , meaning valid. Table 1 shows the instrument reliability. 
Table 1. Instrument reliability test reliability statistics

\begin{tabular}{ccc}
\hline Cronbach's Alpha & Cronbach's Alpha based on standardized items & N of items \\
\hline 0.816 & 0.808 & 64 \\
\hline Source: processed with IBM SPSS.21.0 (2020)
\end{tabular}

The Cronbach's Alpha value shown in Table 1 is 0.816 , this value is greater than the standard 0.6 , so it can be said to be reliable. This means that the instrument has passed the test and is suitable for use in collecting research data. Furthermore, the data obtained were analyzed using regression were previously performed the classical assumption test (Ordinary Least Square) as a prerequisite for analysis: 1) Normality test; 2) Multicollinearity test; 3) Heteroscedasticity test; and 4) Autocorrelation test [28, 29]. The hypothesis is tested using the t-test technique.

\section{RESULTS AND DISCUSSION}

\subsection{Online learning in the era of COVID-19 perspective respondents}

Online learning becomes mandatory after the stipulation of coronavirus disease 2019 (COVID-19) as a national epidemic. The transformation of the learning model into online has received mixed responses from academic practitioners. For those who are rich and are in the modern area (downtown), of course, this is a blessing; in contrast to developing regions, for example, West Papua. Online learning receives a low interest in various universities [30]. From the start of internet facilities, the cost of quotas to human resources to use technology is of particular concern. However, the online learning model, especially in Islamic Religious Higher Education, has already become a mandatory choice set by the authorities amid the COVID19 pandemic. Academic actors who are not ready with an online model will be left behind by science [31]. It is essential to know how to ensure the success of this learning model. The quantitative descriptive study of the views of Islamic Religious Higher Education practitioners in West Papua is explained in Table 2.

Table 2. Respondents' responses to research variables

\begin{tabular}{ccc}
\hline Research variable & Average & Criteria score \\
\hline Personal dimensions & 33.67 & Good \\
Characteristics of students & 33.66 & Good \\
Teacher characteristics & 33.76 & Good \\
Internal motivation & 33.58 & Good \\
System dimensions & 33.06 & Enough \\
Institutional quality and services & 33.42 & Good \\
System infrastructure and quality & 23.92 & Enough \\
Course quality and information & 23.84 & Enough \\
Environmental dimensions & 33.58 & Good \\
Good learning environment & 33.58 & Good \\
Online learning success & 33.32 & Enough \\
\hline
\end{tabular}

Source: data processed with Ms. Excel for Windows (2020)

Note: $1.00-1.80$ (very bad); 1.81-2.60 (bad); 2.61-3.40 (enough); 3.41-4.20 (good); 4.21-5.00 (very good) [32]

The measurement of the success of online learning implementation is seen from three dimensions with seven parameters. The first is Personal Dimensions. It includes the characters of students, lecturers, and online learning motivation at IAIN Sorong, STIT Yapis Manokwari, and STAI Al-Mahdi Fakfak are in a suitable category (3.67). The era of technology and learning did from home indeed become a breath of fresh air for the learners. This learning model is following the motivation of those who always use technology or smartphones. The second is System Dimensions with service, infrastructure, and course quality parameters being in the moderate category (3.06). In infrastructure parameters, respondents gave sufficient responses. Infrastructure includes physical or non-physical components used in the continuation of online learning. Among them is the availability of online learning facilities, technology, applications, networks, and access fees or quotas. This good category occurs because during the COVID-19, the facility was not used directly by students or lecturers. This means that they use their own infrastructure to fulfill online learning. Next to the component quality courses or training to strengthen the use of online learning technology. Respondents stated that knowledge in the use of online learning technology was self-taught. Looking for references on the internet, google, YouTube, and very few Islamic Higher Education in Islamic Equity provides guidelines/guidelines for using online learning technology. There was not even comprehensive training. The third is Environmental Dimensions, which is an environmental aspect that supports the implementation of online learning. Respondents gave a good response (3.58), meaning that ecological conditions support the 
implementation of education. Learning from home allows students and lecturers to be relaxed, comfortable, and not awkward.

Some of the results of the descriptive study above, it can be concluded that online learning conducted by three Islamic Higher Education Institutions in West Papua was quite successful. Both from the personal, system, and environmental dimensions, all of them support and are related. This is in line with findings stating that learning is in the 3.32 category (good enough) according to the respondents' perspective.

\subsection{Success factors of COVID-19 era online learning}

Success factors in the implementation of the COVID-19 era online learning in Islamic Religious Higher Education in the West Papua region will be explained based on Table 3. Table 3 presents the results of the regression test. Its function is to map the contribution of influence between variables in supporting online learning success in the COVID-19 era. Before a regression analysis was carried out, a prerequisite test of analysis or a classical assumption test of the regression model with a significance of 5\% $(0.05)[13,17]$. The prerequisite test results show that, normality test $(\mathrm{p}$-value $=0.14)$, multicollinearity $(\mathrm{VIF}=0.28-0.94$ and tolerance=1.1-3.5), autocorrelation (p-value DW=1.97) and heteroscedasticity test ( $\mathrm{p}$-value=0.55-0.92). Following the requirements criteria put forward by Priyatno and Suharmoko, the data can be accepted and continued in the regression test stage [28, 29].

Furthermore, the regression test was used to determine the effect of seven variables on the successful implementation of online learning at Islamic Religious Higher Education in the COVID-19 era. Three dimensions with seven parameters are used to measure the success of online learning. First, the personal dimension with parameters of student characteristics [21], internal motivation [25], and teacher/lecturer characteristics [26]. Second, the system's dimensions with parameters of institutional and service quality, infrastructure, system quality, course quality, and information [25]. Third, the dimensions of the environment with online learning environment parameters [25]. The complete regression test results are shown in Table 3.

Table 3. Regression test results

\begin{tabular}{|c|c|c|c|c|c|}
\hline \multicolumn{6}{|c|}{ Coefficients $^{\mathrm{a}}$} \\
\hline \multirow{2}{*}{ Model } & \multicolumn{2}{|c|}{ Unstandardized coefficients } & \multirow{2}{*}{$\begin{array}{c}\text { Standardized coefficients } \\
\text { Beta }\end{array}$} & \multirow{2}{*}{$\mathrm{t}$} & \multirow{2}{*}{ Sig. } \\
\hline & $\mathrm{B}$ & Std. Error & & & \\
\hline (Constant) & 10.060 & .046 & & 2.486 & .013 \\
\hline Characteristics of students & .585 & .119 & .470 & 4.903 & .000 \\
\hline Teacher characteristics & .340 & .092 & .181 & 2.706 & .049 \\
\hline Internal motivation & .246 & .075 & .178 & 3.296 & .001 \\
\hline Institutional quality and services & .063 & .104 & .058 & .830 & .397 \\
\hline System infrastructure and quality & .942 & .126 & .710 & 7.446 & .000 \\
\hline Course quality and information & .335 & .108 & .325 & 2.989 & .008 \\
\hline Good learning environment & .210 & .082 & .141 & 1.806 & .048 \\
\hline
\end{tabular}

a. Dependent variable: Online learning success

Source: processed with IBM SPSS.21.0 (2020)

From the results of the analysis above, the instructor between the seven variables with the success of online learning in the COVID-19 era in West Papua Islamic Religious Higher Education is described in the form of a regression (1):

$$
\mathrm{Y}=10.060+0.585 \mathrm{X}_{1}+0.340 \mathrm{X}_{2}+0.246 \mathrm{X}_{3}+0.063 \mathrm{X}_{4}+0.942 \mathrm{X}_{5}+0.335 \mathrm{X}_{6}+0.210 \mathrm{X}_{7}
$$

From the multiple linear regression equation above, it can be explained as follows: A constant of 10.060; That is, if the characteristics of students, instructor characteristics, internal motivation, quality and service of institutions, infrastructure and quality of systems, quality of courses and information, and learning environment are worth 0, then the success of online learning in the COVID-19 era in West Papua Islamic Religious Higher Education is $10.060 \%$.

The regression coefficient for the independent variable X1 (student characteristics) is +0.585 ; this means that if the other independent variable values are fixed, then for each addition of the character value of students by one unit (1\%) will lead to an increase in the success of online learning in the COVID-19 era in Islamic Religious Education in West Papua (Y) by 0.585 units (19.5\%). Positive coefficient (+) means there is a positive relationship between the characteristics of students with the success of online learning in the COVID-19 era in Islamic Religious Higher Education, the more (good) the characteristics of students increase the success rate of online learning in the COVID-19 era in Islamic Religious Higher Education West Papua.

Int J Eval \& Res Educ, Vol. 10, No. 1, March 2021: 193 - 201 
The regression coefficient for the independent variable X2 (instructor characteristics) is +0.340 ; this means that if the other independent variable values are fixed, then for each addition of one teacher's (1\%) teacher or lecturer characteristic value will lead to an increase in the success of COVID-19 era online learning in West Papua Islamic Religious Education (Y) of 0.340 units (34.0\%). Positive coefficient (+) means that there is a positive relationship between the characteristics of lecturers with the success of online learning in the COVID-19 era in Islamic Religious Higher Education. Islamic Religion in West Papua.

The regression coefficient for the independent variable X3 (internal motivation) is +0.246 ; this means that if the other independent variable values are fixed, then for each increase in the internal motivation value of lecturers and students by one unit (1\%) will lead to increased success in online learning in the COVID-19 era in West Papua Islamic Religious Higher Education (Y) of 0.246 units (24.6\%). Positive coefficient $(+)$ means that there is a positive relationship between the internal motivation of lecturers and students with the success of online learning in the COVID-19 era in Islamic Religious Higher Education.

The regression coefficient for the independent variable X4 (quality and service institutions) of +0.063 ; meaning that if the other independent variable values remain, then for each additional value of quality and institutional services by one unit (1\%) will lead to increased success in the online learning of the COVID-19 era in Islamic Religious Higher Education, West Papua (Y) by 0.063 units (6.3\%). Positive coefficient $(+)$ means that there is a positive relationship between the internal motivation of lecturers and students with the success of online learning in the COVID-19 era in Islamic Religious Higher Education in Islamic Religious Higher Education, West Papua.

The regression coefficient for the independent variable X5 (infrastructure and system quality) is +0.942 ; meaning that if the other independent variable values remain, then for each additional value of infrastructure and the quality of the network system by one unit (1\%) will lead to the increased success of online learning in the COVID-19 era in Islamic Religious Higher Education, West Papua (Y) by 0.942 units (94.2\%). Positive coefficient (+) means that there is a positive relationship between infrastructure and the quality of the network system with the success of online learning in the COVID-19 era in Islamic Religious Higher Education.

The regression coefficient for the independent variable X6 (quality of courses and information) is +0.335 ; meaning that if the other independent variable values remain, then for each addition of the value of the quality of courses and information by one unit (1\%) will lead to increased success in online learning in the COVID-19 era in Islamic Religious Higher Education, West Papua (Y) of 0.335 units (33.5\%). Positive coefficient $(+)$ means that there is a positive relationship between the quality of courses and information with the success of online learning in the COVID-19 era in Islamic Religious Higher Education, the better (better) the quality of courses and information carried out, the more the success rate of online learning in the COVID -19 era in Islamic Religious Education in West Papua.

The regression coefficient for the independent variable X7 (learning environment) is +0.210 ; meaning that if the other independent variable values are fixed, then for each additional value in the aspect of the learning environment by one unit $(1 \%)$ will lead to the increased success of the online learning of the COVID-19 era in West Papua Islamic Religious Education (Y) by 0.210 units (21.0\%). Positive coefficient (+) means that there is a positive relationship between the learning environment and the success of online learning in the COVID-19 era in Islamic Religious Higher Education, the more (good) the learning environment increases the success rate of online learning in the COVID-19 era in Islamic Religious Higher Education, West Papua.

Furthermore, the Adjusted R Square value is used to see the contribution of the independent variable (X1-X7) consisting of student characteristics, instructor characteristics, internal motivation, quality and institutional services, infrastructure and system quality, course and information quality, and learning environment towards the dependent variable Y (success of COVID-19 era online learning in Islamic Religious Higher Education, West Papua). For regression analysis of more than two independent variables, Adjusted R Square is used as the coefficient of determination [28, 33]. The analysis findings can be seen in Table 4.

Table 4. Determination coefficient test

\begin{tabular}{ccccc}
\hline Model & R & R square & $\begin{array}{c}\text { Model summary } \\
\text { Adjusted R square }\end{array}$ & Std. error of the estimate \\
\hline 1 & $.964^{\mathrm{a}}$ & .929 & .883 & 2.473 \\
\hline
\end{tabular}

a. Predictors: (Constant), Learning environment, course quality and information, teacher characteristics, infrastructure and system quality, internal motivation, student characteristics, institutional quality, and services b. Dependent Variable: The success of online learning

Source: processed with IBM SPSS.21.0 (2020) 
Table 4 shows that the Adjusted R Square value of 0.883 or $(88.3 \%)$ is obtained. This indicates that the contribution of the influence of variables X1-X7 (learning environment, quality of courses and information, instructor characteristics, infrastructure, and system quality, internal motivation, student characteristics, quality, and institutional services) to the dependent variable (success of online learning in the COVID-19 era in Islamic Religious Higher Education, West Papua) of $88.3 \%$ while the remaining $11.7 \%$ is influenced or explained by other variables not analyzed in this research model.

Standard Errors of the Estimate is a measure of the number of errors of the regression model in predicting Y value $[13,17]$. The results of the analysis, according to Table 4, the value of the Standard Error of the Estimate of 2.473, meaning that the number of errors in predicting the success of online learning in the era of COVID-19 in Islamic Religious Higher Education, West Papua was 2.473\% (rounded 2.5\%). Then, the hypothesis test is performed using the t-test. An overview of the results of hypothesis testing can be seen in Table 5.

Table 5. Hypothesis testing with t-test

\begin{tabular}{|c|c|c|c|c|}
\hline Hypothesis & Test method & Criteria & p-value & Results \\
\hline $\begin{array}{l}\text { H1: Students' characteristics have a positive and significant } \\
\text { effect on the success of online learning in the COVID-19 era in } \\
\text { Islamic Religious Higher Education, West Papua }\end{array}$ & & & 0.000 & accepted \\
\hline $\begin{array}{l}\mathrm{H} 2 \text { : teacher characteristics have a positive and significant effect } \\
\text { on the success of online learning in the COVID-19 era in Islamic } \\
\text { Religious Higher Education, West Papua }\end{array}$ & & & 0.049 & accepted \\
\hline $\begin{array}{l}\text { H3: internal motivation has a positive and significant effect on } \\
\text { the success of online learning in the COVID-19 era in Islamic } \\
\text { Religious Higher Education, West Papua }\end{array}$ & & & 0.001 & accepted \\
\hline $\begin{array}{l}\text { H4: Institutional quality and services have a positive and } \\
\text { significant effect on online learning success in the COVID-19 } \\
\text { era in Islamic Religious Higher Education, West Papua }\end{array}$ & t-test & $\begin{array}{l}\text { p-value }<0.05, \\
\text { then the } \\
\text { hypothesis is }\end{array}$ & 0.397 & rejected \\
\hline $\begin{array}{l}\text { H5: infrastructure and system quality have a positive and } \\
\text { significant effect on the success of online learning in the } \\
\text { COVID-19 era in Islamic Religious Higher Education, West } \\
\text { Papua }\end{array}$ & & $\begin{array}{l}\text { accepted and vice } \\
\text { versa }\end{array}$ & 0.000 & accepted \\
\hline $\begin{array}{l}\text { H6: course quality and information have a positive and } \\
\text { significant effect on online learning success in the COVID-19 } \\
\text { era in Islamic Religious Higher Education, West Papua }\end{array}$ & & & 0.008 & accepted \\
\hline $\begin{array}{l}\text { H7: The learning environment has a positive and significant } \\
\text { effect on the success of online learning in the COVID-19 era in } \\
\text { Islamic Religious Higher Education, West Papua }\end{array}$ & & & 0.048 & accepted \\
\hline
\end{tabular}

The results of partial tests using the t-test showed a variety of significant factors that influenced online learning success in the COVID-19 era in West Papua Islamic Religious Education. First, it was found that students' characteristics had a positive and significant effect on online learning success in the COVID-19 era in West Papua Islamic Religious Education. This can be seen in Table 3, where the analysis of the influence of the regression model is $58.5 \%$ positive. Confirmation in Table 5 also shows the p-value $0.000<0.05$, which means that the hypothesis can be accepted. These findings confirm that the characteristics of students with necessary skills, discipline, and high self-esteem can carry out learning by online methods with excellent standards $[8,9,18]$.

Secondly, it was found that the instructor's characteristics had a positive and significant effect on the success of online learning in the COVID-19 era in Islamic Religious Higher Education, West Papua. This can be seen in Table 3, where the results of the analysis of the regression model's influence by $34 \%$ positive. Confirmation in Table 5 also shows the p-value $0.001<0.05$, which means that the hypothesis can be accepted. These findings confirm that the results [26]. Teachers play a central role in ensuring the effectiveness of online learning. Teachers who understand technology, the substance of knowledge, and are positive, tend to be successful in online learning.

Third, related to motivational aspects, internal motivation has a positive and significant effect on online learning success in the COVID-19 era in Islamic Religious Higher Education, West Papua. The analysis results of the impact of a positive regression model of $24.6 \%$ are shown in Table 3 . In Table 5 also confirmed that the p-value $0.049<0.05$, which means the hypothesis can be accepted. The enthusiasm of students and lecturers in learning online will certainly facilitate learning. The more student enthusiasm for learning, and also the teacher's positive response, will facilitate learning. These findings confirm the findings [25] that motivation can maximize the implementation of online learning. 
Fourth, it was found that institutions' quality and service had a positive and not significant effect on online learning success in the COVID-19 era in Islamic Religious Higher Education, West Papua. It can be seen in Table 4, where the analysis of the influence of the regression model is only positive at $6.3 \%$. Confirmation in Table 5 also shows the p-value $0.397<0.05$, which means the hypothesis is rejected. This finding rejects the findings $[10,12]$ on institutional quality and services aspects. It is following respondents' views in Table 1, institutions' quality and service are in a good category. During the COVID-19 pandemic, institutions no longer had a substantial role in online learning. Online learning is carried out in full at each home (learning from home) and the prevention of COVID-19 transmission [3, 19, 34]. This is what makes the institution's quality and services related to online learning irrelevant. The quality and services of institutions will have a major impact if online learning is carried out during normal times. Therefore, institutional service and institutional quality do not guarantee online learning success in the COVID-19 era in Islamic Religious Higher Education in the West Papua region.

Fifth, infrastructure aspects, and system quality. The findings show that infrastructure and system quality positively and significantly affect online learning success in the COVID-19 era in Islamic Religious Higher Education, West Papua. The analysis results of the influence of a positive regression model of 94.2\% are shown in Table 3. Table 5 also confirmed that the p-value $0.000<0.05$, which means the hypothesis can be accepted. When viewed comprehensively from several variables tested, infrastructure and system quality have the most significant impact. The network infrastructure and systems used during online learning have a significant impact on the successful implementation of learning. If network access, quotas, and digital platforms are inadequate, online learning becomes difficult to implement properly, and vice versa. This finding confirms the findings [25] that digital systems' infrastructure and quality have a crucial role in supporting the implementation of online learning [35]. If internet access is limited, the implementation of online learning is difficult to realize $[13,16,19]$.

Sixth, related to aspects of the quality of courses and information. The findings show that the course and information quality have a positive and significant effect on online learning success in the COVID-19 era in Islamic Religious Higher Education, West Papua. The analysis results of the impact of a positive regression model of $33.5 \%$ are shown in Table 3. Table 5 also confirmed that the p-value $0.008<0.05$, which means the hypothesis can be accepted. These findings are in line with results that the quality of courses and services has implications for the success of online learning [25, 27]. The course's quality in question is online learning service user understanding in terms of training and information or technical guidelines for using digital platforms in learning. Users must be introduced to digital platforms that will be used in learning [11]. Learning and skilled learning users will impact the speed of existing learning [7, 22]. Information related to technical guidelines and tutorials on online learning is also needed [17].

Seventh, related to aspects of the learning environment. A conducive, safe, and comfortable environment will undoubtedly make it easier for someone to learn. The findings show that the learning environment has a positive and significant effect on online learning success in the COVID-19 era in Islamic Religious Higher Education, West Papua. The results of the analysis of the influence of the regression model obtained by positive $21.0 \%$ are shown in Table 3 . Table 5 also confirmed that the p-value $0.048<0.05$, which means the hypothesis can be accepted. These findings are consistent with the result that the learning environment has implications for online learning [25]. A safe, comfortable, and relaxed learning environment allows for a more relaxed, flexible, and healthy learning [36, 37].

\section{CONCLUSION}

It turns out that institutions' quality and service is not a determinant factor of the success of online learning in the COVID-19 Era of Islamic Higher Education in West Papua. Institutions no longer have a central role in online learning. Online learning is carried out in full in their respective homes (learning from home) and preventing transmission of COVID-19. This is what makes the quality and services of institutions in terms of online learning irrelevant. The institution's quality and service will have a big impact if online learning is carried out during normal times. Therefore, institutional services and institutional quality do not guarantee online learning success during the COVID-19 period, especially at Islamic Religious Colleges in West Papua. However, the other six aspects also need attention. Aspects of student characteristics, internal motivation, teacher/lecturer characteristics, infrastructure, system quality, course quality and information, and an online learning environment guarantee existing learning success.

Of the six aspects that have positive implications, the system's infrastructure and quality have the most significant influence on online learning success. This matter needs more attention by the government and authorities. Fulfillment of internet network infrastructure with qualified bandwidth and access points in various strategic areas must be optimized. In the COVID-19 era, which requires online learning, the need for and ease of internet access is absolute. Therefore, these findings can be used by authorities in determining 
policies for the implementation of higher education, especially in West Papua. An area with a complexity of problems, a variety of demographics amid the COVID-19 pandemic that continues to increase, these findings are quite worthy of reference.

Several limitations in this research need to be conveyed, including those related to detailed information. The infrastructure and quality of the learning system that contributed the most to online learning success in the COVID-19 era in West Papua need to be explored further. The choice of a qualitative method with an ethnographic perspective is suitable as a unit of analysis. They are combining data collection techniques, both in-depth interviews, observations, and other studies. The goal is that the research findings' substance can explain more comprehensively the existing online learning situation.

\section{ACKNOWLEDGEMENTS}

Authors are very grateful to the leaders of the Islamic College in West Papua: The Rector of the Sorong State Islamic Institute; the Head of the Tarbiyah School of Science, Yapis Manokwari, and the Head of the Al-Mahdi Fakfak Islamic College for allowing us to conduct the research. Furthermore, authors would also like to thank the respondents and colleagues who have provided a lot of meaningful information to complete this research.

\section{REFERENCES}

[1] A. Pininta, "Minister of Education and Culture: Higher Education in All Zones Prohibited Face-to-Face Lecture," Kompas, 2020. [Online]. Available: https://www.kompas.com/edu/read/2020/06/16/103917571/mendikbud (accessed Jun. 17, 2020).

[2] S. Adnan, "Islamic Universities are Urged to Start Distance Learning Process," Oase, 2020. [Online]. Available: https://m.oase.id/read/a3K89W- (accessed May 17, 2020).

[3] GTPP COVID-19 RI, Protocol for the Acceleration of Handling the COVID-19 Pandemic (Corona Virus Disease 2019). Jakarta: Indonesian COVID-19 Handling Acceleration Task Force, 2020.

[4] I. Hidayati, "History of Population Mobility to the City of Sorong - West Papua," LIPI, 2019. [Online]. Available: https://kependudukan.lipi.go.id/id/kajian-kependudukan/migrasi/632 (accessed Jul. 06, 2020).

[5] K. D. I. K. M. Dinas Persandian, "History of Manokwari \& Its Development," Department of Encryption, 2019. [Online]. Available: http://www.manokwarikab.go.id/halaman/sejarah-manokwari (accessed Jun. 02, 2020).

[6] M. Rajab, "Evaluation and Optimization of Online Learning," DetikNews, 2020. [Online]. Available: https://news.detik.com/kolom/d-4960905/evaluasi (accessed Jun. 12, 2020).

[7] S. Agarwal and J. S. Kaushik, "Student's Perception of Online Learning during COVID Pandemic," Indian J. Pediatr., vol. 87, no. 7, pp. 554-554, Jul. 2020, doi: 10.1007/s12098-020-03327-7.

[8] M. Masterson, "An Exploration of the Potential Role of Digital Technologies for Promoting Learning in Foreign Language Classrooms: Lessons for a Pandemic," Int. J. Emerg. Technol. Learn., vol. 15, no. 14, p. 83, Jul. 2020, doi: 10.3991/ijet.v15i14.13297.

[9] R. A. Pangondian, P. I. Santosa, and E. Nugroho, "Factors Affecting the Success of Online Learning in the Industrial Revolution 4.0," in National Seminar on Computer Technology \& Science, 2019, vol. 1, no. 1.

[10] N. G. Biavardi, "Being an Italian medical student during the COVID-19 outbreak," Int. J. Med. Students, vol. 8, no. 1, pp. 49-50, Apr. 2020, doi: 10.5195/ijms.0.489.

[11] C. Owusu-Fordjour, C. K. Koomson, and D. Hanson, "The impact of COVID-19 on learning-the perspective of the Ghanaian student," Eur. J. Educ. Stud., vol. 7, no. 3, pp. 88-101, 2020, doi: 10.5281/zenodo.3753586.

[12] T. Favale, F. Soro, M. Trevisan, I. Drago, and M. Mellia, "Campus traffic and e-Learning during COVID-19 pandemic," Comput. Networks, vol. 176, no. July, p. 107290, Jul. 2020, doi: 10.1016/j.comnet.2020.107290.

[13] E. Windhiyana, "The Impact of COVID-19 on Online Learning Activities in Christian Universities in Indonesia," PIP J., vol. 34, no. 1, pp. 1-8, Apr. 2020, doi: 10.21009/PIP.341.1.

[14] Z. I. Almarzooq, M. Lopes, and A. Kochar, "Virtual Learning During the COVID-19 Pandemic," J. Am. Coll. Cardiol., vol. 75, no. 20, pp. 2635-2638, May 2020, doi: 10.1016/j.jacc.2020.04.015.

[15] A. Yudiawan, "Learning With COVID 19: Evaluation of Pandemic Era Online Learning at the State Islamic Religious College, West Papua," AL-FIKR J. Pendidik. Islam, vol. 6, no. 1, pp. 10-16, Aug. 2020, doi: 10.32489/alfikr.v6i1.64.

[16] G. Gunawan, N. M. Y. Suranti, and F. Fathoroni, "Variations of Models and Learning Platforms for Prospective Teachers During the COVID-19 Pandemic Period," Indones. J. Teach. Educ., vol. 1, no. 2, pp. 61-70, 2020.

[17] W. Bao, "COVID-19 and Online Teaching in Higher Education: A case study of Peking University," Hum. Behav. Emerg. Technol., vol. 2, no. 2, pp. 113-115, Apr. 2020, doi: 10.1002/hbe2.191.

[18] M. A. Almaiah, A. Al-Khasawneh, and A. Althunibat, "Exploring the critical challenges and factors influencing the E-learning system usage during COVID-19 pandemic," Educ. Inf. Technol., May 2020, doi: 10.1007/s10639-02010219-y.

[19] I. A. Adeoye, A. F. Adanikin, and A. Adanikin, "COVID-19 and E-Learning: Nigeria Tertiary Education System Experience,” Int. J. Res. Innov. Appl. Sci., vol. V, no. V, pp. 2454-6194, 2020. 
[20] Kemristekdikti, "Data on Higher Education in West Papua," Center for Data Information, Ministry of Research, Technology and Higher Education, 2019. [Online]. Available: https://pddikti.kemdikbud.go.id/data_pt/OTRBQ0ExQTItMEFENy00RTgyLUE3RkEtMjFCNTU1NENEQzVE (accessed Jun. 05, 2020).

[21] D. E. Leidner and S. L. Jarvenpaa, "The Information Age Confronts Education: Case Studies on Electronic Classrooms," Inf. Syst. Res., vol. 4, no. 1, pp. 24-54, Mar. 2012, doi: 10.1287/isre.4.1.24.

[22] M. Aparicio, F. Bacao, and T. Oliveira, "Grit in the path to e-learning success," Comput. Human Behav., vol. 66, no. January, pp. 388-399, Jan. 2017, doi: 10.1016/j.chb.2016.10.009.

[23] G. H. Shakah, A. T. Al-Oqaily, and F. Alqudah, "Motivation Path between the Difficulties and Attitudes of Using the E-Learning Systems in the Jordanian Universities: Aajloun University as a Case Study," Int. J. Emerg. Technol. Learn., vol. 14, no. 19, p. 26, Oct. 2019, doi: 10.3991/ijet.v14i19.10551.

[24] N. H. Al-Ajmi and Z. Aljazzaf, "Factors Influencing the Use of Multimedia Technologies in Teaching English Language in Kuwait," Int. J. Emerg. Technol. Learn., vol. 15, no. 05, p. 212, Mar. 2020, doi: 10.3991/ijet.v15i05.12277.

[25] W. Bhuasiri, O. Xaymoungkhoun, H. Zo, J. J. Rho, and A. P. Ciganek, "Critical success factors for e-learning in developing countries: A comparative analysis between ICT experts and faculty," Comput. Educ., vol. 58, no. 2, pp. 843-855, Feb. 2012, doi: 10.1016/j.compedu.2011.10.010.

[26] C. L. Dillon and C. N. Gunawardena, "A Framework For The Evaluation of Telecommunications-Based Distance Education," in 17th Congress of the International Council for Distance Education, Open University, Milton Keynes, 2011, pp. 348-351.

[27] A. Y. Alsabawy, A. Cater-Steel, and J. Soar, "Determinants Of Perceived Usefulness Of E-Learning Systems," Comput. Human Behav., vol. 64, no. November, pp. 843-858, Nov. 2016, doi: 10.1016/j.chb.2016.07.065.

[28] D. Priyatno, Independent Learning Data Analysis with SPSS. Yogyakarta: MediaKom, 2013.

[29] A. Yudiawan and S. Suharmoko, "Multivariate Regression Analysis Principle Components Analysis with Ordinary Least Square to Measure Significance of Student Decision Factors in Choosing State Islamic Higher Education," Al-Qisthu J. Kaji. Ilmu-ilmu Huk., vol. 17, no. 2, p. 70, Mar. 2020, doi: 10.32694/010790.

[30] T. Lestari, "Online Learning Survey during the COVID 19 Pandemic at the UPI Cibiru Campus," Indonesian Education University, 2020. [Online]. Available: http://berita.upi.edu/25031/ (accessed Jun. 20, 2020).

[31] T. Volery and D. Lord, "Critical success factors in online education," Int. J. Educ. Manag., vol. 14, no. 5, pp. 216-223, Sep. 2010, doi: 10.1108/09513540010344731.

[32] H. Umar, Research Methods for Thesis and Business Thesis. Jakarta: PT.Raja Grafindo Persada, 2014.

[33] S. Santoso, Parametric Statistics, Revised Edition. Jakarta: Media Komputindo, 2014.

[34] A. Hasanah, A. S. Lestari, A. Y. Rahman, and Y. I. Daniel, "Analysis of Student Online Learning Activities during the COVID-19 Pandemic," UIN Sunan Gunung Djati Bandung, 2020.

[35] L. Pham, K. Kim, B. Walker, T. DeNardin, and H. Le, "Development and Validation of an Instrument to Measure Student Perceived E-Learning Service Quality,” Int. J. Enterp. Inf. Syst., vol. 15, no. 2, pp. 15-42, Apr. 2019, doi: 10.4018/IJEIS.2019040102.

[36] M. B. Arzhanik, E. V. Chernikova, S. I. Karas, and E. Y. Lemeshko, "Differentiated Approach to Learning in Higher Education," Procedia - Soc. Behav. Sci., 2015, pp. 287-291, doi: 10.1016/j.sbspro.2014.12.525.

[37] S. Minocha and A. J. Reeves, "Design of learning spaces in 3D virtual worlds: an empirical investigation of Second Life," Learn. Media Technol., vol. 35, no. 2, pp. 111-137, Jun. 2010, doi: 10.1080/17439884.2010.494419. 